IRA-International Journal of Applied Sciences

ISSN 2455-4499; Vol.04, Issue 03 (2016)

Institute of Research Advances

Pg. no. 358-378

http://research-advances.org/index.php/IRAJAS

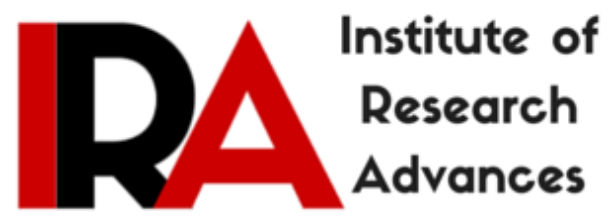

\title{
ABCD analysis of Dye-doped Polymers for Photonic Applications
}

\author{
Shubhrajyotsna Aithal ${ }^{1}$ and P. S. Aithal ${ }^{2}$ \\ ${ }^{1}$ Srinivas School of Engineering, Mukka, Mangalore - 574146, India. \\ ${ }^{2}$ Srinivas Institute of Management Studies, Pandeshwar, Mangalore - 575 001, India.
}

Type of Review: Peer Reviewed.

DOI: http://dx.doi.org/10.21013/jas.v4.n3.p1

\section{How to cite this paper:}

Aithal, S., \& Aithal, P. (2016). ABCD analysis of Dye-doped Polymers for Photonic Applications. IRA-International Journal of Applied Sciences (ISSN 2455-4499), 4(3), 358-378. doi:http://dx.doi.org/10.21013/jas.v4.n3.p1

(C) Institute of Research Advances

\section{(cc) EY-NO}

This work is licensed under a Creative Commons Attribution-Non Commercial 4.0 International License subject to proper citation to the publication source of the work.

Disclaimer: The scholarly papers as reviewed and published by the Institute of Research Advances (IRA) are the views and opinions of their respective authors and are not the views or opinions of the IRA. The IRA disclaims of any harm or loss caused due to the published content to any party. 


\section{ABSTRACT}

Photonics is a subject of scientific study on generating, controlling, harvesting and detecting the beam of photons or light with a purpose of creating, manipulating, storing, transmitting and detecting information using nonlinear optical properties of materials. This paper is a new attempt to integrate scientific research and social research by analysing the characteristics of dye-doped polymer films for photonics applications. The analysing framework called ABCD framework to analyse any business concepts, business systems, technology, strategy, engineering material, technology or even an idea systematically by identifying the advantages, benefits, constraints, and disadvantages under various determinant issues and listing the constituent critical elements under each construct. In this paper, as per the $A B C D$ framework, the various determinant issues related to the use of dye-doped polymer films for photonic applications through focus group method are determined as affecting factors under: (1) Material Issues, (2) Application Issues, (3) Commercialization Issues, (4) Production/Service providers Issues, (5) Customer Issues, and (6) Environmental/Social Issues. The constituent critical elements of these factors are listed under the four constructs - advantages, benefits, constraints and disadvantages of the ABCD technique and tabulated. The analysis has brought about 204 critical constituent elements which satisfy the success of this analysis methodology.

Keywords: Nonlinear optical materials, Dye-doped polymer films, ABCD analysis, Constituent critical elements.

\section{Introduction}

Nonlinear optics is expected to play an important role in the field of photonics which is a multidisciplinary new frontier of science and technology capturing the imagination of scientists and engineers worldwide due to its potential applications in optical communication, and optical computation. According to the definition, Photonics is the technology of generating and harnessing light and other forms of radiant energy whose quantum unit is the photon. The range of applications of photonics extends from energy generation to detection to communication and information processing using nonlinear optical properties of materials. The major challenge of photonics is identifying a right material/device to optimally process the signals for a right application using material science and chemical engineering knowledge. Materials with exceptional nonlinear optical properties are critical to the continuing development of photonic and electro-optical devices, such as those used in optical communications, networking, Optical computation for signal processing, and data storage equipment. The nonlinear optical material is a general term for the materials efficiently makes the appearance of nonlinear phenomenon optically as the responses to optical wavelength conversion, optical amplification as well as the refractive index changes due to its intensity. Nonlinear optical materials are largely divided into inorganic and organic materials. In 1930, the nonlinear optical effect related to optical wavelength conversion was predicted, which was said to be the first finding knowledge about the nonlinear optical phenomenon. In 1960, laser oscillation using inorganic material was reported. Since then research of inorganic nonlinear optical materials were actively taken place, but now-a-days, probably there is no more that undiscovered [1]. With the rapid development of modern science and technology, information transmission capacity of communication increases day by day. Optical communication, which has advantages of large transmission capacity, high transmission velocity, excellent anti-jamming ability and good Signal-to-Noise value, is becoming the main method in communication research at present. Functions like optical switching and memory by nonlinear optical effects, all depending on light intensity, are expected to result in the realization of a pivotal optical device in optical computing. This is a new data processing system that makes the maximum use of light characteristics such as parallel and spatial processing capabilities and high speed [2]. 
All-optical networks with good performances, such as big capacity, good transparency, wavelength routing characteristics, compatibility, and extensibility, has become the first choice of next generation of the wide-band net with a promising application. Accompanied by the deep research of wave division multiplex (WDM), switches have drawn more and more people's attention. In the existing opticalelectronic-optical conversion apparatus of present communication net, disadvantages of slow switching speed and clock displacement have lead to a "bottleneck" of optical fiber communication systems. Alloptical switches which can break through the transmission speed limits of electro-optical, acousto-optical, thermo-optical and micro-electro-mechanical switches, can serve as effective methods to solve these problems. Based on the third-order nonlinear optical (NLO) effect, phase all-optical switches use a controlled light to bring changes of refraction index and make phase difference when signal light passes through the sample and thus carry out the function of "on" or "off' of optical switches. Its nonlinear phase difference is proportional to $(2 \pi / \lambda) n_{2} I L$, where $I$ is intensity, $L$ is the length of interaction of wave and $n_{2}$ is nonlinear refraction index. The properties, such as change speed, intensity loss, sensitivity to optical polarization and insert loss, all depend on third-order NLO materials used to synthesize apparatuses. At present, it is with great enthusiasm to an emphasis on exploring and synthesis of materials for all-optical switches based on the continual discovery of varies kinds of new materials. There are other applications of third-order NLO materials, including optical limiting devices, Q-switch, passive mode locking, optical operation and light storage etc. Laser weapons applied to military have special effects on optical-electro antagonism, aerial defense and military recovery. Laser blinding can make eyes blind temporarily or permanently, and laser can also destroy important apparatus in the satellite, such as detectors and sensors. As a result, laser protection materials and devices have become a focus. The purpose of laser protection is to protect people and devices from the damage of high intensity. These optical limiting devices are mainly based on the materials' third-order NLO properties, including self-focusing, self-defocusing, two-photon absorption, reverse saturable absorption and nonlinear scattering. Comparing to earlier laser protection devices, it has advantages of fast response, wide protected band, low optical limiting threshold, large damage threshold and high linear transmission, etc. The third-order NLO properties of materials can also be used in the compression (mode-locking) and shaping of laser pulses, optical bistability, etc. Thirdorder NLO materials also have many potential practical exciting applications and motivated scientists to continually explore new materials with high third-order NLO properties. The demands of materials for all-optical information process and high-speed all-optical switches include large nonlinear refraction index, small linear and nonlinear absorption coefficient, fast response and low propagation loss [1-3].

Photonic and electro-optical (in which information storage or processing involves the modulation and switching of light beams) devices are used in many applications which include :

- Electro-optic modulators

- Mach-Zehnder interferometers

- Optical switches

- Optical interconnectors

- Frequency doublers for high-power lasers

- Active waveguides

- Optical memory storage devices

- Optical computing devices

- Nonlinear directional couplers

- Nonlinear Bragg reflectors

- Optical limiters

- Photorefractive memories

Currently, a wide range of inorganic non-linear optical materials is available [2-3] with varied wavelengths, damage thresholds, and optical characteristics. The research focus is to develop materials that meet all requirements such as faster response, high laser damage threshold, and wide transparency range coupled with adaptability, processing ability, and the ability to interface with other materials. Further, robust growth in demand for high bandwidth fiber optic networking infrastructure and high-speed 
optical computing are expected to boost the demand for Non-Linear Optical Materials [1]. Doped inorganic nonlinear crystals are also shown optical limiting properties [4-7]. Studies showed that by means of heavy ion irradiation one can improve the material properties of both inorganic and organic nonlinear crystals [8-11].

It is well known that one can improve the performance of any system by comparing it with a hypothetical, predicted system of that kind called "Ideal system" [12]. Ideal properties of a device or a system can be used to upgrade or improve its properties towards reaching 100\% efficiency. By comparing the properties/characteristics of a practical device/system with its ideal counterpart, one can find out the possible modifications in that device /system towards reaching the objective of achieving such an ideal system [13]. Many systems like an ideal gas, ideal fuel, ideal solution, ideal fluid, ideal engine, ideal switch, ideal voltage source, ideal current source, ideal diode, ideal transistor, and ideal amplifier are familiar to everybody since school days. Recently, ideal business system [13-14], ideal education system [15-17], ideal technology system [12], ideal strategy [18], ideal energy source [19], ideal banking system [20], and ideal library system [21] are studied and their input, system, output and environmental characteristics are discussed. The properties of the ideal nonlinear material are interesting to know. In table 1 , we have summarized the ideal properties of the nonlinear optical material.

Table 1 . Ideal Properties of optical nonlinear material.

\begin{tabular}{|l|l|l|}
\hline S. No & Property & Value \\
\hline 1 & Nonlinear Susceptibility & Infinity (High) \\
\hline 2 & Refractive index & Low \& constant value \\
\hline 3 & Dielectric property & Low \\
\hline 4 & Material property & optimum \\
\hline 5 & Material Processing & Easy \\
\hline 6 & Colour & Transparent and colourless \\
\hline 7 & Transmission range & Infinite \\
\hline 8 & Durability & Life time without degradation \\
\hline 9 & Laser damage threshold & High \\
\hline 10 & Transmission range & Infinite \\
\hline 11 & Material state & Solid (Film \& Fiber) \\
\hline 12 & Electro-optic Coefficient & Infinity (High) \\
\hline 13 & Photoconductivity & Infinity (High) \\
\hline 14 & Photorefractive co-efficient & Infinity (High) \\
\hline 15 & Degradation with time & No \\
\hline 16 & Cost & Zero \\
\hline 17 & Availability & Abundant \\
\hline 18 & Environmental degradation & Zero \\
\hline 19 & Weight & Zero (Low) \\
\hline
\end{tabular}

From the year 1982, organic nonlinear optical material research got importance due to their advantages compared to the inorganic counterpart. It is found that organic compounds with the delocalized conjugated electrons which have excellent nonlinear optical property and high-speed responsiveness due to the high mobility of electrons. Based on predictions, the 21st century is said to be an age of photonics. As one of the basic technology of photonics, improvements in the wavefront control technology using organic nonlinear optical effects are considered very important and hence research on the organic materials with excellent nonlinear optical properties, and exceptional material properties have been studied. Present developments in the field of materials chemistry show that, though inorganic materials are still the choices for many devices, interest, and scope for organic materials are growing day-by-day in view of their adaptability to various kinds of applications. The field of organic molecular materials has 
transformed the use of materials in the modern world in the last 40 years, and it can be seen that organic molecules provide wonderful opportunities to materials researchers to design custom-tailored materials whose properties at the macroscopic /microscopic level reflect closely to the modeled or actual behavior of individual molecules. In other words, development of novel functional organic materials is a rapidly growing area of science, which probably can replace the traditionally used materials with cheaper and better-performing new ones in the near future, and also bring out some new applications [22-24]. Research also has shown that many organic crystals have better nonlinear susceptibility compared to inorganic crystals [25-26].

In view of the technological applications of the organic materials, the current research focus is in five technical areas, which are (1) Structural and multifunctional materials, (2) Energy and power materials, (3) Photonic and Electronic Materials, (4) Functional organic and hybrid materials, (5) Bio-derived and bio-inspired materials. Organic nonlinear materials are currently finding importance due to their advantages and benefits for photonics device fabrication. Some of the benefits of organic nonlinear optical materials are:

- Easy to process: Because they do not require electric poling or the preparation of large single crystals, these materials are easier to process than inorganic optical materials.

- Lower cost: The ease of processing directly translates into a lower cost to fabricate.

- High second- and third-order susceptibility: This technology exhibits exceptional performance in doubling and tripling the frequency of light passing through it, making it at least comparable to inorganic materials.

- Low dielectric constant: An optical material with a high dielectric constant requires a larger poling voltage in order to polarize the dipole moment and can suffer changes in the refractive index. This technology requires no poling voltage and maintains its refractive index.

- High electro-optic coefficient: Materials with a high electro-optic coefficient are more suitable for electro-optic modulation for high-speed devices.

- Colorless: It is believed that the clarity of the doubling material will prevent the absorption of visible light, allowing a wide variety of light frequencies to be doubled.

- Resistant to laser damage: The tripling material can be exposed to 4,32,000 20-nanosecond pulses at $20 \mathrm{~Hz}$ without any evidence of damage to the organic material, making it ideal for use in photonic applications.

\section{Dye - Doped Polymers for Photonic Applications}

Though the present best practice in Photonics technology is the usage of organic materials/dyes that exhibit exceptional nonlinear optical properties, these organic materials have few of the drawbacks inherent in the processing of comparable inorganic materials like of intense light induced degradation or bleaching and aggregation at higher dye concentration. In order to overcome these drawbacks and for effective use of highly nonlinear dyes, the strategic idea for the next practice is doping the dye molecules in the polymer matrix. This idea of dye-doped polymer material matrix may increase the concentration of absorptive or fluorescence centers as well as the opto-chemical and opto-physical stability [27-28]. A large number of organic compounds with delocalized electrons and conjugated double bond systems, and a large dipole moment has been studied to realize the susceptibilities far larger than the inorganic optical materials [29]. The organic compounds and dyes molecules with two basic structural families of acceptor/donor/donor/acceptor and donor/bridge/acceptor have shown high two photon absorption properties. Such information can be useful in the design of more efficient two-photon dyes for imaging and power-limiting applications. Organic dye doped polymer films are used for (1) Optical amplification, (2) Rewritable optical data storage, (3) optical information storage, (4) Spatial light modulation, (5) Optical power limiting [30-33], (6) Photonic switching [34], (7) Quasi-permanent alloptical encoding [35], (8) Two photon florescence microscopy [36], (9) Frequency up-converted lasing, 
(10) Three dimensional optical storage, (11) Two photon induced optical imaging, (12) photosensitive media for holographic recording and optical computing, (13) Ultrafast all-optical devices. (14) Optical phase conjugation [37-39], (15) Optical parametric oscillator using four-wave mixing [40-41], and (16) controlling light by light through optical spatial solitons [42]. Many studies have been conducted to measure nonlinear optical properties like third harmonic generation properties [43], optical limiting studies [44] and optical phase conjugation using four-wave mixing studies [45] in various nonlinear dyes doped in polymer films. In this paper, we have made an attempt to analyse nonlinear dye-doped polymer films for nonlinear and photonic applications using recently developed analysis framework called ABCD analysis framework. The acronym ABCD stands for Advantages, Benefits, Constraints, and Disadvantages.

\section{About ABCD Analysis}

Various techniques are used to analyze the individual characteristics, system characteristics, effectiveness of a concept or idea, effectiveness of a strategy while studying the business value in the society. The individual characteristics or organizational effectiveness \& strategies in a given environment can be studied using SWOT analysis, SWOC analysis, PEST analysis, McKinsey 7S framework, ICDT model, Portor's five force model etc. Recently introduced business analysis framework called ABCD analysis framework [46] is suitable for analysing business concepts, business systems, technology, business models or business idea in terms of determining various factors for chosen determinant issues under four constructs called advantages, benefits, constraints, and disadvantages. In the qualitative analysis using $\mathrm{ABCD}$ framework, the concept/system/strategy/technology/model/idea is further analysed by identifying constitutional critical factors. In the quantitative analysis using ABCD framework [47], the appropriate score/weightage is given to each constituent critical factor under each construct, through empirical research, the total score is calculated for each construct and by evaluating the scores, the concept/idea/system/technology/strategy can be accepted or rejected. Thus ABCD analysis framework can be used as a research tool in these areas and is a simple but systematic analyzing technique for business models/systems/concepts/ideas/technology/strategy analysis.

\section{Literature Review on ABCD Analysis}

In 2015, Aithal P.S. et. al. [46] developed ABCD analyzing framework to analyze any business model/strategy/concept/system and to study its effectiveness in providing value to its stakeholders and sustainable profit through expected revenue generation. Application of $\mathrm{ABCD}$ analysis results in an organized list of business advantages, benefits, constraints, and disadvantages in a systematic matrix. The entire framework is divided into various issues/area of focus and various business deployment factors affecting the business/concept can be identified and analyzed under each issue by identifying the suitable critical effective element. This analyzing technique being simple gives he guideline to identify and analyze the effectiveness of any business model, business strategy, business concept/idea, and business system.

Reshma et. al. [48], have analyzed the characteristics of "Working from Home" e-business model using 'ABCD Analysis Technique'. Based on various factors which decide the Working from Home system, a model of various factors and their constituent critical elements affecting under organizational objectives, employers point of view, employees point of view, customers/students point of view, environmental/societal point of view and system requirements are derived from a qualitative data collection instrument namely focus group method. It is found that the factors supporting advantages and benefits are more effective compared to constraints and disadvantages of this model so that working from the home model may become more popular from the perspective of employers and employees in the organization in the future. 
ABCD analysis framework is used for analysing Black Ocean Strategy (BOS) concept [49]. The various factors \& their constituent critical factors affecting the BOS concept adopted in some of the business organizations for quick relief from the problems are identified for organizational point of view, administrative point of view, employee point of view, operational point of view, business point of view and external issues point of view are determined under the four constructs - advantages, benefits, constraints, and disadvantages.

ABCD analysis framework has been used for analysis of a concept "Higher Education Stage Model". The characteristics of the concept are evaluated based on identifying and analyzing the advantages, benefits, constraints, and disadvantages. The result supported the logic of using ABCD analyzing technique in any concept/idea performance evaluation [50].

$\mathrm{ABCD}$ analysis framework is also used for analysing National Assessment and Accreditation Council (NAAC) accreditation process on higher education institutions [51]. The various features of the NAAC accreditation system is evaluated based on identifying and analyzing the advantages, benefits, constraints, and disadvantages of some of the chosen issues like organizational issues, Faculty performance issues, student development/progression issues, social/environmental/community engagement issues, Infrastructure And Learning resources, and Issues on Innovations Creativity and Best Practices. The affecting factors under these issues found out using focus group method and the constituent critical elements under each factor are identified. The result supported the logic of using ABCD analyzing technique in any System/concept performance evaluation.

In another paper on "Study on ABCD Analysis Technique for Business Models, business strategies, Operating Concepts \& Business Systems", the author discussed the detailed ABCD framework for quantitative studies and explained how this framework can be used for four specific instances namely Business model, Business strategy, Operational concept and Functional system are outlined here. Finally, ABCD analysing framework is compared with other known analyzing techniques like SWOC, Competitive Profile Matrix (CPM) analysis, EFE \& IFE Matrices, BCG analysing frameworks, Porter's Five Forces Model, and PESTLE Analysis [47].

Application of ABCD Analysis Framework on Private University System in India is another paper published using this model in which for six determinant issues related to the functioning of a University has been chosen. These are Organizational aspects, Students Progression, Faculty development, Societal $\&$ other stakeholders issues, Governance, Leadership, and Issues on Innovations and Best Practices. Four key issues were identified under each of these and critical constituent elements under these factors are worked out. Through this analysis, 192 critical constituent elements which satisfy the success of a private university have been explored [52].

Recently, another paper on "Study of New National Institutional Ranking Framework (NIRF) System using ABCD Framework, is published in which the ranking system is evaluated using four constructs Advantages, Benefits, Constraints, and Disadvantages, this system consider all determinant issues in key areas through analyzing the major issues and identifying the critical constituent elements and concluded that NIRF provides a comprehensive ranking suitable for higher educational institutions and it takes care of many small and subtle aspects comparable to quality assessment criterion of National Assessment and Accreditation Council. [53].

Apart from using ABCD framework for Qualitative analysis, in several research studies, ABCD analysis is limited and simplified to only listing of various advantages, benefits, constraints, and disadvantages of either concept, models, systems, strategies, technology, or ideas [54-60]. These studies on ABCD listing can be analysed in detail using $\mathrm{ABCD}$ framework either qualitatively or quantitatively for further research. 


\section{ABCD Analysis on Dye-doped Polymers}

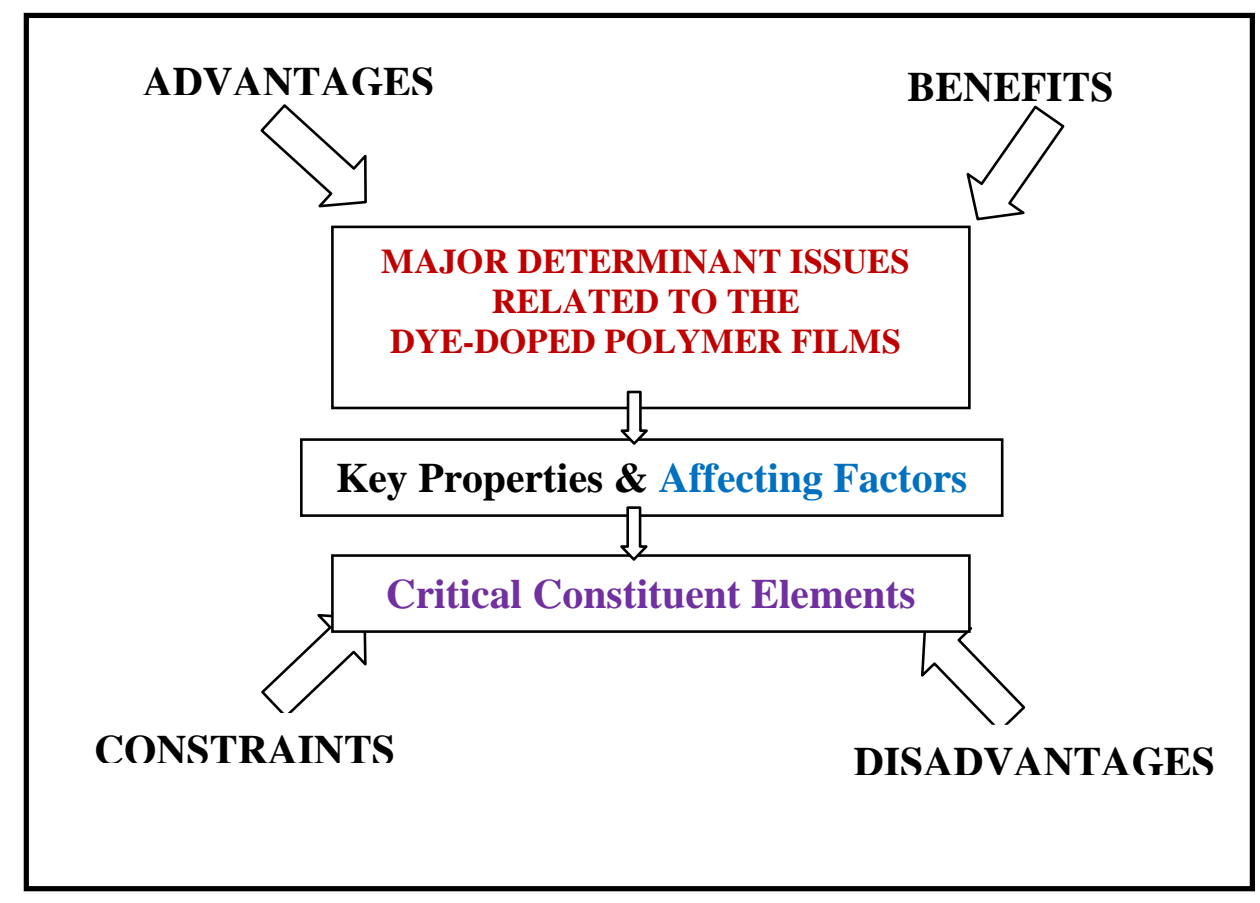

Figure. 1 . Block diagram of issues affecting the dye-doped polymer films for photonic applications as per ABCD framework.

Advantages, Benefits, Constraints and Disadvantages (ABCD) of a System can be used to analyze and understand the model/system in an effective way. As per this analysis technique, the effectiveness of a material system can be studied by identifying and analyzing the advantages, benefits, constraints, and disadvantages by considering various determinant issues related to the use of dye-doped polymers for photonic applications as shown in the block diagram (fig. 1). As per the ABCD framework, the various determinant issues related to the success of dye-doped polymer films in photonic applications identified using focus group method [61] are : (1) Material Issues, (2) Application Issues, (3) Commercialization Issues, (4) Production/Service providers Issues, (5) Customer Issues, and (6) Environmental/Social Issues.

(1) Material Issues :

The affecting factors under key properties like Processing for device fabrication, Third order susceptibility, Laser damage threshold, Electro-optic coefficient value, and Dielectric constant value are determinant factors under the constructs Advantages, Benefits, Constraints, and Disadvantages of the System.

(2) Application Issues :

The affecting factors under key properties like Optical limiting, Electro-optic modulators, Photorefractive memories, Optical switches, and Optical computer components are determined under the constructs Advantages, Benefits, Constraints, and Disadvantages of the System.

(3) Commercialization Issues :

The affecting factors under key properties like Easy to process, Low cost, High reliability, and Long life are determined under the constructs Advantages, Benefits, Constraints, and Disadvantages of the System. 
(4) Production/Service providers Issues :

The affecting factors under key properties like Production cost, Performance, Durability, and Raw materials availability are determined under the constructs Advantages, Benefits, Constraints, and Disadvantages of the System.

(5) Customer Issues :

The affecting factors under key properties like Quality, Durability, Cost, and Availability are determined under the constructs Advantages, Benefits, Constraints, and Disadvantages of the System.

(6) Environmental/Society Issues :

The affecting factors under key properties like Environmental degradation, Social perception, Future scope, and Recycling are determined under the constructs Advantages, Benefits, Constraints, and Disadvantages of the System.

Each determinant issue has sub-issues called key properties used for analyzing the advantages, benefits, constraints and disadvantages, the four constructs of the framework. The factors affecting the various determinant issues of private university system for each key issue under four constructs are derived by a qualitative data collection instrument namely, focus group method [61-68], and are listed in table 2.

Table 2 . Analysis of the dye-doped polymer films for photonic applications using ABCD framework.

\begin{tabular}{|c|c|c|c|c|c|}
\hline $\begin{array}{l}\text { Determinant } \\
\text { Issues }\end{array}$ & $\begin{array}{l}\text { Key } \\
\text { Properties }\end{array}$ & Advantages & Benefits & Constraints & Disadvantages \\
\hline \multirow[t]{5}{*}{$\begin{array}{l}\text { Material } \\
\text { Properties } \\
\text { Issues }\end{array}$} & $\begin{array}{l}\text { Processing for } \\
\text { device } \\
\text { fabrication }\end{array}$ & $\begin{array}{l}\text { Easy to } \\
\text { fabricate as } \\
\text { thin films }\end{array}$ & $\begin{array}{l}\text { Microfilm } \\
\text { component } \\
\text { for device } \\
\text { fabrication }\end{array}$ & $\begin{array}{l}\text { Maintaining } \\
\text { uniform } \\
\text { thickness and } \\
\text { surface }\end{array}$ & $\begin{array}{l}\text { Low physico- } \\
\text { chemical } \\
\text { stability. }\end{array}$ \\
\hline & $\begin{array}{l}\text { Third order } \\
\text { susceptibility }\end{array}$ & $\begin{array}{l}\text { High third } \\
\text { order } \\
\text { susceptibility }\end{array}$ & $\begin{array}{l}\text { Enhanced } \\
\text { efficiency }\end{array}$ & $\begin{array}{l}\text { Depending } \\
\text { on film } \\
\text { thickness }\end{array}$ & $\begin{array}{l}\text { Bleaching of } \\
\text { dye for long } \\
\text { time }\end{array}$ \\
\hline & $\begin{array}{l}\text { Laser damage } \\
\text { threshold }\end{array}$ & $\begin{array}{l}\text { Effective } \\
\text { performance at } \\
\text { Low power } \\
\text { laser }\end{array}$ & $\begin{array}{l}\text { Suitable for } \\
\text { low power } \\
\text { devices }\end{array}$ & $\begin{array}{l}\text { Sample may } \\
\text { burn at high } \\
\text { intensity } \\
\text { laser beam }\end{array}$ & $\begin{array}{l}\text { Low damage } \\
\text { thresh } \\
\text { old }\end{array}$ \\
\hline & $\begin{array}{l}\text { Electro-optic } \\
\text { coefficient } \\
\text { value }\end{array}$ & $\begin{array}{l}\text { High at low } \\
\text { applied } \\
\text { electric field }\end{array}$ & $\begin{array}{l}\text { High } \\
\text { breakdown } \\
\text { voltage }\end{array}$ & $\begin{array}{l}\text { Applying } \\
\text { external dc } \\
\text { electric field } \\
\text { is difficult }\end{array}$ & $\begin{array}{l}\text { E-O } \\
\text { coefficient } \\
\text { varies with } \\
\text { wavelength of } \\
\text { laser beam }\end{array}$ \\
\hline & $\begin{array}{l}\text { Dielectric } \\
\text { constant value }\end{array}$ & $\begin{array}{l}\text { Low dielectric } \\
\text { constant }\end{array}$ & $\begin{array}{l}\text { No poling } \\
\text { voltage } \\
\text { required }\end{array}$ & $\begin{array}{l}\text { Applying } \\
\text { external dc } \\
\text { electric field } \\
\text { is difficult }\end{array}$ & $\begin{array}{l}\text { Dielectric } \\
\text { constant varies } \\
\text { with } \\
\text { wavelength of } \\
\text { laser beam }\end{array}$ \\
\hline $\begin{array}{l}\text { Application } \\
\text { Issues }\end{array}$ & $\begin{array}{l}\text { Optical } \\
\text { limiting }\end{array}$ & $\begin{array}{l}\text { Limiting of } \\
\text { High intensity } \\
\text { laser light }\end{array}$ & $\begin{array}{l}\text { Eye } \\
\text { protection } \\
\text { when }\end{array}$ & $\begin{array}{l}\text { Limiter at all } \\
\text { wavelengths }\end{array}$ & $\begin{array}{l}\text { Nonlinear } \\
\text { refraction } \\
\text { property of }\end{array}$ \\
\hline
\end{tabular}




\begin{tabular}{|c|c|c|c|c|c|}
\hline & & & $\begin{array}{l}\text { working with } \\
\text { laser beams }\end{array}$ & & dye \\
\hline & $\begin{array}{l}\text { Electro-optic } \\
\text { modulators }\end{array}$ & $\begin{array}{l}\text { High electro- } \\
\text { optic } \\
\text { coefficient }\end{array}$ & Fast response & $\begin{array}{l}\text { High voltage } \\
\text { requirement } \\
\text { for } \\
\text { modulation }\end{array}$ & $\begin{array}{l}\text { Low physico- } \\
\text { chemical } \\
\text { stability }\end{array}$ \\
\hline & $\begin{array}{l}\text { Photorefractive } \\
\text { memories }\end{array}$ & $\begin{array}{l}\text { High PR } \\
\text { coefficient }\end{array}$ & $\begin{array}{l}\text { High density } \\
\text { storage at } \\
\text { high retrieval } \\
\text { speed }\end{array}$ & $\begin{array}{l}\text { Doping is } \\
\text { required to } \\
\text { increase } \\
\text { trapping } \\
\text { centers }\end{array}$ & $\begin{array}{l}\text { Temperature } \\
\text { dependent } \\
\text { properties }\end{array}$ \\
\hline & $\begin{array}{l}\text { Optical } \\
\text { switches }\end{array}$ & $\begin{array}{l}\text { Fast optical } \\
\text { response }\end{array}$ & $\begin{array}{l}\text { High figure } \\
\text { of merit }\end{array}$ & $\begin{array}{l}\text { Doping is } \\
\text { required to } \\
\text { increase } \\
\text { charge } \\
\text { centers }\end{array}$ & $\begin{array}{l}\text { Slow time } \\
\text { response }\end{array}$ \\
\hline & $\begin{array}{l}\text { Optical } \\
\text { computer } \\
\text { components }\end{array}$ & $\begin{array}{l}\text { Easy to } \\
\text { fabricate thin } \\
\text { film \& fibers }\end{array}$ & $\begin{array}{l}\text { High speed } \\
\text { response }\end{array}$ & $\begin{array}{l}\text { Doping is } \\
\text { required to } \\
\text { increase } \\
\text { charge } \\
\text { centers }\end{array}$ & $\begin{array}{l}\text { Low physico- } \\
\text { chemical } \\
\text { stability }\end{array}$ \\
\hline $\begin{array}{l}\text { Commercializ } \\
\text { ation Issues }\end{array}$ & Easy to process & $\begin{array}{l}\text { Easy to } \\
\text { fabricate as } \\
\text { thin films and } \\
\text { fibers }\end{array}$ & $\begin{array}{l}\text { Less } \\
\text { expensive } \\
\text { equipments } \\
\text { required }\end{array}$ & $\begin{array}{l}\text { Tedious } \\
\text { process }\end{array}$ & $\begin{array}{l}\text { Colour of dye } \\
\text { decreases the } \\
\text { transparency } \\
\text { range }\end{array}$ \\
\hline & Low cost & Less expensive & $\begin{array}{l}\text { Easily } \\
\text { available in } \\
\text { the market }\end{array}$ & $\begin{array}{l}\text { Low profit } \\
\text { due to low } \\
\text { cost }\end{array}$ & $\begin{array}{l}\text { More } \\
\text { competitors }\end{array}$ \\
\hline & High reliability & $\begin{array}{l}\text { Stable } \\
\text { nonlinear } \\
\text { properties }\end{array}$ & $\begin{array}{l}\text { Used for } \\
\text { longer period }\end{array}$ & $\begin{array}{l}\text { Degradation } \\
\text { of } \\
\text { performance } \\
\text { for longer } \\
\text { period }\end{array}$ & $\begin{array}{l}\text { Low phisico- } \\
\text { chemical } \\
\text { stability }\end{array}$ \\
\hline & Long life & $\begin{array}{l}\text { Stable } \\
\text { nonlinear } \\
\text { properties for } \\
\text { long time }\end{array}$ & $\begin{array}{l}\text { High laser } \\
\text { damage } \\
\text { threshold }\end{array}$ & $\begin{array}{l}\text { Delicate for } \\
\text { replacement }\end{array}$ & $\begin{array}{l}\text { Not withstands } \\
\text { at higher laser } \\
\text { intensity }\end{array}$ \\
\hline $\begin{array}{l}\text { Production/Se } \\
\text { rvice }\end{array}$ & Production cost & Low & $\begin{array}{l}\text { Less } \\
\text { expensive }\end{array}$ & Assembling & $\begin{array}{l}\text { Periodical } \\
\text { Replacement }\end{array}$ \\
\hline $\begin{array}{l}\text { providers } \\
\text { Issues }\end{array}$ & Performance & $\begin{array}{l}\text { Higher } \\
\text { susceptibility }\end{array}$ & Fast response & $\begin{array}{l}\text { Anti- } \\
\text { reflection } \\
\text { coating }\end{array}$ & $\begin{array}{l}\text { Degrades with } \\
\text { time }\end{array}$ \\
\hline & Durability & Long time & $\begin{array}{l}\text { Less after } \\
\text { sales service }\end{array}$ & $\begin{array}{l}\text { Periodic } \\
\text { service }\end{array}$ & $\begin{array}{l}\text { Less life with } \\
100 \text { efficiency }\end{array}$ \\
\hline
\end{tabular}




\begin{tabular}{|c|c|c|c|c|c|}
\hline & $\begin{array}{l}\text { Raw materials } \\
\text { availability }\end{array}$ & $\begin{array}{l}\text { Easily } \\
\text { available }\end{array}$ & Cheap & $\begin{array}{l}\text { Uniform } \\
\text { doping }\end{array}$ & $\begin{array}{l}\text { Environmental } \\
\text { degradation of } \\
\text { dyes }\end{array}$ \\
\hline \multirow[t]{4}{*}{$\begin{array}{l}\text { Customer } \\
\text { Issues }\end{array}$} & Quality & $\begin{array}{l}\text { High nonlinear } \\
\text { properties }\end{array}$ & $\begin{array}{l}\text { Easy } \\
\text { processing }\end{array}$ & Soft material & $\begin{array}{l}\text { Bleaching of } \\
\text { dye after } \\
\text { several years }\end{array}$ \\
\hline & Durability & $\begin{array}{l}\text { Long life with } \\
\text { expected } \\
\text { performance }\end{array}$ & $\begin{array}{l}\text { Worth } \\
\text { investment }\end{array}$ & $\begin{array}{l}\text { Maintaining } \\
\text { outer surface } \\
\text { of thin } \\
\text { sample }\end{array}$ & $\begin{array}{l}\text { Bleaching of } \\
\text { dye after } \\
\text { several years }\end{array}$ \\
\hline & Cost & $\begin{array}{l}\text { Low cost } \\
\text { device }\end{array}$ & Low price & $\begin{array}{l}\text { Periodic up } \\
\text { gradation }\end{array}$ & $\begin{array}{l}\text { Periodic } \\
\text { replacement }\end{array}$ \\
\hline & Availability & $\begin{array}{l}\text { Easily } \\
\text { available }\end{array}$ & $\begin{array}{l}\text { Anywhere } \\
\text { usage }\end{array}$ & $\begin{array}{l}\text { Simple } \\
\text { component }\end{array}$ & $\begin{array}{l}\text { Supply of } \\
\text { components }\end{array}$ \\
\hline \multirow[t]{4}{*}{$\begin{array}{l}\text { Environmental } \\
\text { /Society } \\
\text { Issues }\end{array}$} & $\begin{array}{l}\text { Environmental } \\
\text { degradation }\end{array}$ & $\begin{array}{l}\text { No green gas } \\
\text { emission }\end{array}$ & $\begin{array}{l}\text { Low } \\
\text { environment } \\
\text { al effect }\end{array}$ & $\begin{array}{l}\text { Careful } \\
\text { handling }\end{array}$ & $\begin{array}{l}\text { Dyes are } \\
\text { poisonous }\end{array}$ \\
\hline & $\begin{array}{l}\text { Social } \\
\text { perception }\end{array}$ & $\begin{array}{l}\text { Advanced } \\
\text { device for } \\
\text { society }\end{array}$ & $\begin{array}{l}\text { High speed } \\
\text { device }\end{array}$ & $\begin{array}{l}\text { Environment } \\
\text { al effect }\end{array}$ & $\begin{array}{l}\text { Low phisico- } \\
\text { chemical } \\
\text { stability }\end{array}$ \\
\hline & Future scope & $\begin{array}{l}\text { High } \\
\text { performance } \\
\text { devices }\end{array}$ & $\begin{array}{l}\text { Advanced } \\
\text { technology } \\
\text { usage }\end{array}$ & $\begin{array}{l}\text { Availability } \\
\text { of dyes }\end{array}$ & $\begin{array}{l}\text { Threat of } \\
\text { better } \\
\text { components } \\
\text { based on } \\
\text { nanotechnolog } \\
\text { y }\end{array}$ \\
\hline & Recycling & Possible & $\begin{array}{l}\text { No } \\
\text { degradation }\end{array}$ & Dye stability & $\begin{array}{l}\text { Dye may } \\
\text { degrade } \\
\text { drinking water }\end{array}$ \\
\hline
\end{tabular}

\section{Critical Constituent Elements as per ABCD model}

The critical constituent elements of these factors are listed under the four constructs - advantages, benefits, constraints and disadvantages of the ABCD technique and tabulated in tables 3 to 6 . 
Table 3 : Advantages of dye-doped polymers for photonic applications

\begin{tabular}{|c|c|c|c|}
\hline $\begin{array}{l}\text { Sl. } \\
\text { No. }\end{array}$ & Issue & Factors affecting & Critical Constituent Elements \\
\hline \multirow[t]{10}{*}{1.} & \multirow[t]{10}{*}{ Material Issues } & \multirow{2}{*}{$\begin{array}{l}\text { Easy to fabricate as thin } \\
\text { films \& fibers }\end{array}$} & Easy for spin coating \\
\hline & & & Easy for hot press method \\
\hline & & \multirow[t]{2}{*}{$\begin{array}{l}\text { High third order } \\
\text { susceptibility }\end{array}$} & $\begin{array}{l}\text { Non-centrosymmetric } \\
\text { structure }\end{array}$ \\
\hline & & & Do not require electric poling \\
\hline & & \multirow[t]{2}{*}{$\begin{array}{l}\text { Effective performance at } \\
\text { Low power laser }\end{array}$} & $\begin{array}{l}\text { Active for } \mathrm{CW} \text { laser beam \& pulsed } \\
\text { laser beam }\end{array}$ \\
\hline & & & $\begin{array}{l}\text { Active for low power UV, visible, and } \\
\text { IR region }\end{array}$ \\
\hline & & \multirow{2}{*}{$\begin{array}{l}\text { High at low applied electric } \\
\text { field }\end{array}$} & Effective polarization \\
\hline & & & High breakdown voltage \\
\hline & & \multirow[t]{2}{*}{ Low dielectric constant } & Polarization ability \\
\hline & & & Electric field strength \\
\hline \multirow[t]{10}{*}{2.} & \multirow{10}{*}{$\begin{array}{l}\text { Application } \\
\text { Issues }\end{array}$} & \multirow{2}{*}{$\begin{array}{l}\text { Limiting of High intensity } \\
\text { laser light }\end{array}$} & High nonlinear absorption \\
\hline & & & Wide transparency range \\
\hline & & \multirow[t]{2}{*}{ High electro-optic coefficient } & Variation of transmission amplitude \\
\hline & & & High modulation index \\
\hline & & \multirow[t]{2}{*}{$\begin{array}{ll}\text { High } & \text { Photorefractive } \\
\text { coefficient }\end{array}$} & $\begin{array}{l}\text { Refractive index variation with light } \\
\text { intensity }\end{array}$ \\
\hline & & & Charge transfer properties \\
\hline & & \multirow[t]{2}{*}{ Fast optical response } & Free carriers \\
\hline & & & Optical bistability \\
\hline & & \multirow{2}{*}{$\begin{array}{l}\text { Easy to fabricate thin film \& } \\
\text { fibbers }\end{array}$} & Surface tension \\
\hline & & & Strength of fibres \\
\hline \multirow[t]{8}{*}{3.} & \multirow{8}{*}{$\begin{array}{l}\text { Commercializati } \\
\text { on Issues }\end{array}$} & \multirow{2}{*}{$\begin{array}{l}\text { Easy to fabricate as thin } \\
\text { films and fibers }\end{array}$} & Material property \\
\hline & & & Tensile strength \\
\hline & & \multirow[t]{2}{*}{ Less expensive } & Easy availability \\
\hline & & & Simple processes \\
\hline & & \multirow[t]{2}{*}{ Stable nonlinear properties } & Non-centrosymmetry \\
\hline & & & Non-bleaching \\
\hline & & \multirow{2}{*}{$\begin{array}{l}\text { Stable nonlinear properties } \\
\text { for long time }\end{array}$} & Material type \\
\hline & & & Stable dye $\&$ polymer used \\
\hline \multirow[t]{8}{*}{4.} & \multirow{8}{*}{$\begin{array}{l}\text { Production/Serv } \\
\text { ice providers } \\
\text { Issues }\end{array}$} & \multirow[t]{2}{*}{ Low production cost } & Easy component processing \\
\hline & & & $\begin{array}{l}\text { Availability of raw materials at low } \\
\text { price }\end{array}$ \\
\hline & & \multirow[t]{2}{*}{ Higher susceptibility } & Quality of raw materials \\
\hline & & & Organic nonlinear materials \\
\hline & & \multirow[t]{2}{*}{ Long time } & Functioning \\
\hline & & & Same conversion efficiency \\
\hline & & \multirow[t]{2}{*}{ Easily available } & Abundant \\
\hline & & & Low cost \\
\hline 5. & Customer Issues & High nonlinear properties & Non-centrosymmetry \\
\hline & & & Efficiency \\
\hline & & Long life with expected & Faithfull operation \\
\hline & & performance & Expected performance \\
\hline & & Low cost device & Low price \\
\hline
\end{tabular}


IRA-International Journal of Applied Sciences

\begin{tabular}{|c|c|c|c|}
\hline & & & Easy replacement \\
\hline & & Easily available & Abundant \\
\hline & & & Continuous supply \\
\hline 6. & Environmental/ & No green gas emission & Clean operation \\
\hline & Society Issues & & Clean environment \\
\hline & & Advanced device for society & Latest technology \\
\hline & & & Environmental sustainability \\
\hline & & High performance devices & Efficiency \\
\hline & & & Best output \\
\hline & & Recycling Possible & Low degradation \\
\hline & & & Sustainability \\
\hline
\end{tabular}

Table 4 : Benefits of the dye-doped polymers for photonic applications

\begin{tabular}{|c|c|c|c|}
\hline $\begin{array}{l}\text { Sl. } \\
\text { No. }\end{array}$ & Issue & Factors affecting & Critical Constituent Elements \\
\hline \multirow[t]{10}{*}{1.} & \multirow[t]{10}{*}{ Material Issues } & \multirow{2}{*}{$\begin{array}{l}\text { Microfilm component for } \\
\text { device fabrication }\end{array}$} & Small device \\
\hline & & & Simple device \\
\hline & & \multirow[t]{2}{*}{ Enhanced efficiency } & Best performance \\
\hline & & & Better output \\
\hline & & \multirow{2}{*}{$\begin{array}{l}\text { Suitable for low power } \\
\text { devices }\end{array}$} & Low cost \\
\hline & & & Low input energy \\
\hline & & \multirow[t]{2}{*}{ High breakdown voltage } & Sustaining strong electric field \\
\hline & & & High polarizability \\
\hline & & \multirow{2}{*}{$\begin{array}{l}\text { No poling voltage } \\
\text { required }\end{array}$} & Natural nonlinearity \\
\hline & & & Low cost \\
\hline \multirow[t]{10}{*}{2.} & \multirow[t]{10}{*}{ Application Issues } & \multirow{2}{*}{$\begin{array}{l}\text { Eye protection when } \\
\text { working with laser beams }\end{array}$} & Low transmission at high intensity \\
\hline & & & High laser damage threshold \\
\hline & & \multirow[t]{2}{*}{ Fast response } & $\begin{array}{l}\text { Effective at nano and femto second } \\
\text { regime }\end{array}$ \\
\hline & & & High modulation index \\
\hline & & \multirow{2}{*}{$\begin{array}{l}\text { High density storage at } \\
\text { high retrieval speed }\end{array}$} & High space charge field \\
\hline & & & Refractive Index grating \\
\hline & & \multirow[t]{2}{*}{ High figure of merit } & High optical bistability \\
\hline & & & Low noise for amplification \\
\hline & & \multirow[t]{2}{*}{ High speed response } & High speed grating \\
\hline & & & High speed storage \& retrieval \\
\hline \multirow[t]{8}{*}{3.} & \multirow{8}{*}{$\begin{array}{l}\text { Commercialization } \\
\text { Issues }\end{array}$} & \multirow{2}{*}{$\begin{array}{l}\text { Less } \quad \text { expensive } \\
\text { equipments required }\end{array}$} & Simple and easy process \\
\hline & & & Less and cheaper raw materials \\
\hline & & \multirow{2}{*}{$\begin{array}{l}\text { Easily available in the } \\
\text { market }\end{array}$} & Abundant supply of raw materials \\
\hline & & & Minimum raw materials requirement \\
\hline & & \multirow[t]{2}{*}{ Used for longer period } & Trouble free operations \\
\hline & & & Minimum energy consumption \\
\hline & & \multirow{2}{*}{$\begin{array}{l}\text { High laser damage } \\
\text { threshold }\end{array}$} & Durability \\
\hline & & & No periodic material replacement \\
\hline \multirow[t]{4}{*}{4.} & \multirow{4}{*}{$\begin{array}{l}\text { Production/Service } \\
\text { providers Issues }\end{array}$} & \multirow[t]{2}{*}{ Less expensive } & Low investment \\
\hline & & & Small component size \\
\hline & & \multirow[t]{2}{*}{ Fast response } & Material property \\
\hline & & & Amount of doping \\
\hline
\end{tabular}


IRA-International Journal of Applied Sciences

\begin{tabular}{|c|c|c|c|}
\hline & & Less after sales service & No frequent breakdown \\
\hline & & & Easy repairing/replacement \\
\hline & & Cheap & Simple raw materials \\
\hline & & & Component in the form of thin film. \\
\hline 5. & Customer Issues & Easy processing & Simple process \\
\hline & & & No special care needed \\
\hline & & Worth investment & No periodic replacement \\
\hline & & & Return on investment \\
\hline & & Low price & Affordability \\
\hline & & & High demand \\
\hline & & Anywhere usage & Simple operations \\
\hline & & & Easy procurement \\
\hline 6. & Environmental/Soci & Low environmental effect & Emission \\
\hline & ety Issues & & Recycling \\
\hline & & High speed device & Technology \\
\hline & & & Speed \\
\hline & & Advanced & Comfortability \\
\hline & & usage & Better facilities \\
\hline & & No degradation & Poisonous gas \\
\hline & & & Green house effect \\
\hline
\end{tabular}

Table 5 : Constraints of the dye-doped polymers for photonic applications

\begin{tabular}{|c|c|c|c|}
\hline $\begin{array}{l}\text { Sl. } \\
\text { No. }\end{array}$ & Issue & Factors affecting & Critical Constituent Elements \\
\hline \multirow[t]{10}{*}{1.} & \multirow[t]{10}{*}{ Material Issues } & \multirow{2}{*}{$\begin{array}{l}\text { Maintaining thickness and } \\
\text { surface }\end{array}$} & Viscosity \\
\hline & & & Surface Tension \\
\hline & & \multirow{2}{*}{ 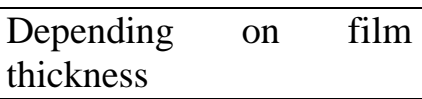 } & Noncentrosymmetry \\
\hline & & & Doping concentration \\
\hline & & \multirow{2}{*}{$\begin{array}{l}\text { Sample may burn at high } \\
\text { intensity laser beam }\end{array}$} & Phisico-chemical stability \\
\hline & & & Power of input light \\
\hline & & \multirow{2}{*}{$\begin{array}{l}\text { Applying external dc } \\
\text { electric field is difficult }\end{array}$} & Electric field intensity \\
\hline & & & Film thickness \\
\hline & & \multirow{2}{*}{$\begin{array}{l}\text { High } \mathrm{AC} \text { electric field is } \\
\text { required for modulation }\end{array}$} & Material property \\
\hline & & & Modulation index \\
\hline \multirow[t]{8}{*}{2.} & \multirow[t]{8}{*}{ Application Issues } & \multirow[t]{2}{*}{ Limiter at all wavelengths } & Material transmission range \\
\hline & & & Nonlinear refractive index \\
\hline & & \multirow{2}{*}{$\begin{array}{l}\text { High voltage requirement } \\
\text { for modulation }\end{array}$} & Electro-optic coefficient \\
\hline & & & Modulating voltage strength \\
\hline & & \multirow{2}{*}{$\begin{array}{l}\text { Doping is required to } \\
\text { increase trapping centers }\end{array}$} & Space charge \\
\hline & & & Dye concentration \\
\hline & & \multirow{2}{*}{$\begin{array}{l}\text { Doping is required to } \\
\text { increase charge centers }\end{array}$} & Nature of Dye \\
\hline & & & Intensity variation of external light \\
\hline \multirow[t]{5}{*}{3} & \multirow{5}{*}{$\begin{array}{l}\text { Commercialization } \\
\text { Issues }\end{array}$} & \multirow[t]{2}{*}{ Tedious process } & Thickness monitoring \\
\hline & & & Uniform doping \\
\hline & & \multirow{2}{*}{$\begin{array}{l}\text { Low profit due to low } \\
\text { cost }\end{array}$} & Less investment \\
\hline & & & Low price \\
\hline & & Degradation & Dye bleaching \\
\hline
\end{tabular}


IRA-International Journal of Applied Sciences

\begin{tabular}{|c|c|c|c|}
\hline & & $\begin{array}{l}\text { performance for longer } \\
\text { period }\end{array}$ & Film cracking \\
\hline & & Delicate for replacement & Thin film \\
\hline & & & Trouble free performance \\
\hline 4. & Production/Service & Assembling & Delicate \\
\hline & providers Issues & & Simple processes \\
\hline & & Anti-reflection coating & Enhanced interaction of light \\
\hline & & & Avoid reflection of light \\
\hline & & Periodic service & Film replacement \\
\hline & & & Easy service \\
\hline & & Uniform doping & Proper solvent \\
\hline & & & Uniform drying \\
\hline 5 . & Customer Issues & Soft material & Polymer as backbone \\
\hline & & & Film between glass plates \\
\hline & & Maintaining outer surface & Antireflection coating \\
\hline & & of thin sample & Film between thin glass plates \\
\hline & & Periodic up gradation & Increases performance \\
\hline & & & Easy \\
\hline & & Simple component & Susceptibility for damage \\
\hline & & & Easy replacement \\
\hline 6. & Environmental/Soci & Careful handling & Fragile \\
\hline & ety Issues & & Complete replacement \& recycling \\
\hline & & Environmental effect & Dyes are poisonous \\
\hline & & & Degradability of dyes \\
\hline & & Availability of dyes & Nature of dye \\
\hline & & & Supply of dye \\
\hline & & Dye stability & Component replacement \\
\hline & & & Easy recycling \\
\hline
\end{tabular}

Table 6: Disadvantages of the dye-doped polymers for photonic applications

\begin{tabular}{|c|c|c|c|}
\hline $\begin{array}{l}\text { Sl. } \\
\text { No. }\end{array}$ & Issue & Factors affecting & Critical Constituent Elements \\
\hline \multirow[t]{11}{*}{1.} & \multirow[t]{11}{*}{ Material Issues } & \multirow{2}{*}{$\begin{array}{l}\text { Low physico-chemical } \\
\text { stability. }\end{array}$} & Softness of film \\
\hline & & & Fragileness/brittleness \\
\hline & & \multirow{2}{*}{$\begin{array}{l}\text { Bleaching of dye for long } \\
\text { time }\end{array}$} & Reaction with atmosphere \\
\hline & & & Reaction of dye with light beam \\
\hline & & \multirow[t]{3}{*}{ Low damage threshold } & Intensity of pulsed laser beam \\
\hline & & & Choice of polymer base \\
\hline & & & Dye concentration \\
\hline & & \multirow{2}{*}{$\begin{array}{l}\text { E-O coefficient varies } \\
\text { with wavelength of laser } \\
\text { beam }\end{array}$} & Material property with laser wavelength \\
\hline & & & Nature of dye \\
\hline & & \multirow{2}{*}{$\begin{array}{l}\text { Dielectric constant varies } \\
\text { with wavelength of laser } \\
\text { beam }\end{array}$} & Polarizability \\
\hline & & & Bandwidth \\
\hline \multirow[t]{3}{*}{2} & \multirow[t]{3}{*}{ Application Issues } & \multirow{2}{*}{$\begin{array}{l}\text { Nonlinear refraction } \\
\text { property of dye }\end{array}$} & Material property \\
\hline & & & Wavelength of light \\
\hline & & physico-chemical & Instability in electro-optic property \\
\hline
\end{tabular}


IRA-International Journal of Applied Sciences

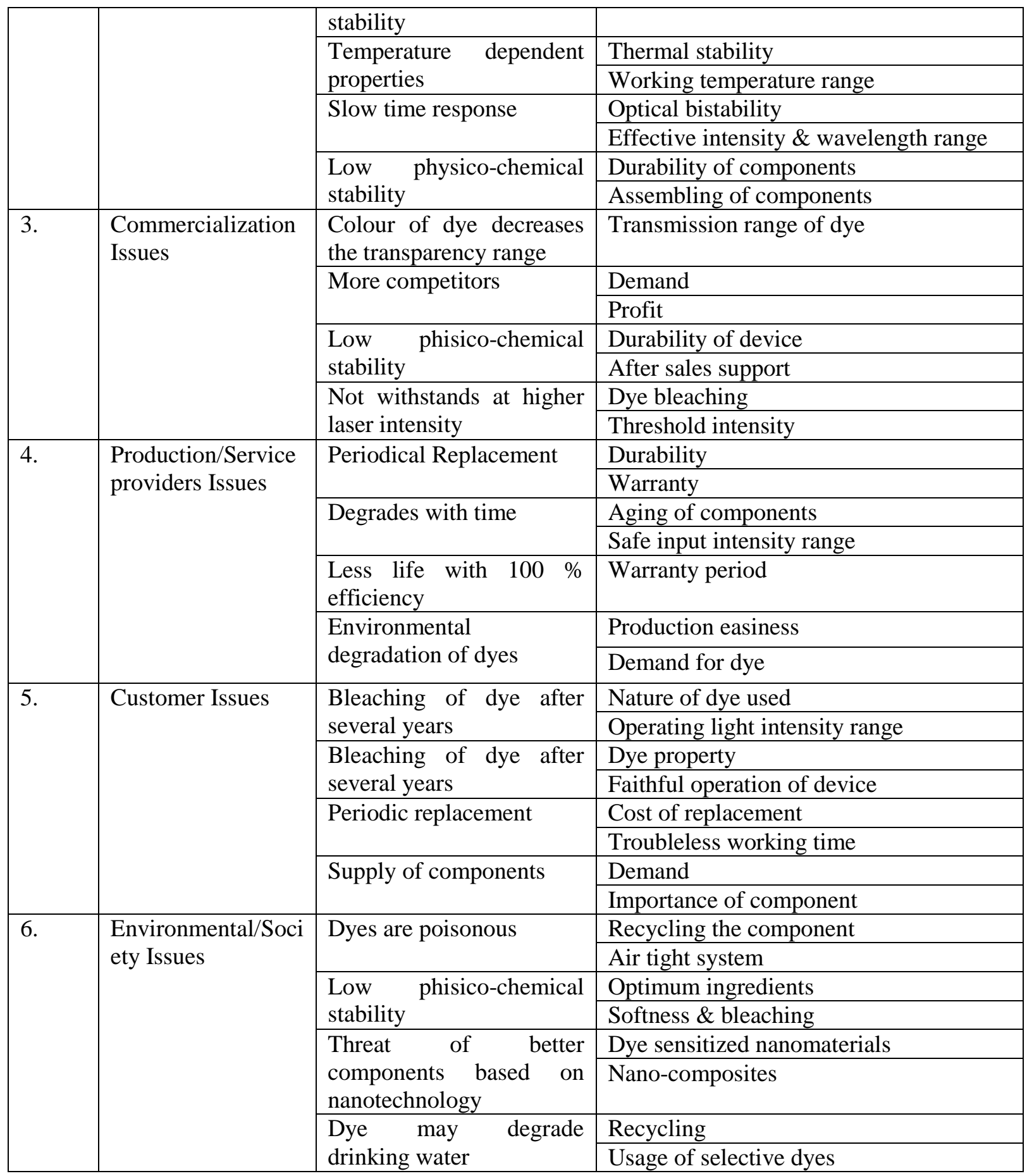

\section{Conclusion}

We have studied the application of dye-doped polymer films for nonlinear and photonics processes using ABCD analysis framework. The various determinant issues of related to the use of dye-doped polymer films in photonic applications identified using focus group method are : (1) Material Issues, (2) Application Issues, (3) Commercialization Issues, (4) Production/Service providers Issues, (5) Customer Issues, and (6) Environmental/Social Issues. The analysis identified the affecting factors for various determinant issues under four constructs advantages, benefits, constraints, and disadvantages. 
The analysis has brought about 204 critical constituent elements which satisfy the success of this analysis methodology.

\section{References}

[1] Sutherland, R.L., McLean, D.G., and Kirkpatrick, S. (2003). Handbook of Nonlinear Optics, 2nd Edition, Marcel Dekker, New York.

[2] Stegeman, G I, Torruellas, W E., (1996). Nonlinear materials for information processing and communications. Philos Trans $R$ Sot Land Phys Sci Eng, 354, 745-756.

[3] Sheik-Bahae M, Said AA, Wei T-H, Hagan DJ, Van Stryland EW. (1990). Sensitive measurement of optical nonlinearities using a single beam. IEEE Journal of Quantum Electronics, 26, 760-769.

[4] Aithal, P.S., Kiran, P.P., Rao, D. N., (1999). Self-focusing, self-trapping, and optical limiting of light beams in photorefractive $\mathrm{Bi}_{12} \mathrm{SiO}_{20}$ : Fe crystal, International Symposium on Photonics and Applications, 406-416.

[5] Aithal P. S., Kiran P. P., and Rao D. N., (1999). Optical Limiting Study in Pure and Doped $\mathrm{Bi}_{12} \mathrm{SiO}_{20}$ Crystals, International Conference on Laser Materials and Devices., Allied Publishers, 106-111.

[6] Aithal, P. S., Singh, R. P., Kiran, P.P., \& Rao D. N., (2000). Optical limiting and nonlinear absorption studies in $\mathrm{Bi}_{12} \mathrm{SiO}_{20}$ crystal at high power nanosecond laser regime. Asian Journal of Physics, 9(1), 107114.

[7] Aithal, P. S., Kiran, P. P., \& Rao D. N. (2000). Optical limiting studies in photorefractive pure and iron-doped $\mathrm{Bi}_{12} \mathrm{SiO}_{20}$ crystals, Journal of Nonlinear Optical Physics \& Materials, 9(2), 217-225.

[8] Bhat, A. P., Aithal, P. S., Rao, P. M., \& Avasthi, D. K., (1996). Effect of Heavy Ion Irradiation on Dielectric Properties of ADP and Doped ADP Crystals, Materials Science Forum, 223, 213-216.

[9] Bhat, A. P., Aithal, P. S., Rao, P. M., \& Avasthi, D. K. (2000). Effects of swift heavy ions on the dielectric properties of doped and undoped ammonium dihydrogen phosphate crystals, Nuclear Instruments and Methods in Physics Research Section B: Beam Interactions with Materials and Atoms, 166, 964-967.

[10] Rao, P. M., Nagaraja, H. S., Aithal, P. S., Avasthi, D. K., \& Sarma, A. (1998). Effect of high energy ion irradiation on electrical and optical properties of organic nonlinear optical crystals, Materials chemistry and physics, 54(1), 147-150.

[11] Aithal, P. S., Nagaraja, H. S., Rao, P. M., Nampoori, V. P. N., Vallabhan, C. P. G., and Avasthi, D. K. (1997). Possibility of waveguide formation on organic nonlinear crystal methyl para-hydroxy benzoate using high energy ion irradiation, Nuclear Instruments and Methods in Physics Research Section B: Beam Interactions with Materials and Atoms, 129(2), 217-220.

[12] Aithal, P. S., \& Shubhrajyotsna Aithal, (2015). Ideal Technology Concept \& its Realization Opportunity using Nanotechnology, International Journal of Application or Innovation in Engineering \& Management (IJAIEM), 4(2), 153 - 164.

[13] Aithal, P. S. (2015). Concept of Ideal Business \& Its Realization Using E-Business Model, International Journal of Science and Research (IJSR), 4(3), 1267 - 1274.

[14] Aithal, P. S., (2015). Mobile Business as an Optimum Model for Ideal Business. International Journal of Management, IT and Engineering (IJMIE), 5(7), 146-159.

[15] Aithal, P. S., \& Shubhrajyotsna Aithal (2015). An Innovative Education Model to realize Ideal Education System. International Journal of Scientific Research and Management (IJSRM), 3(3), 24642469. 
[16] Aithal, P. S., \& Shubhrajyotsna Aithal, (2014). Ideal education system and its realization through online education model using mobile devices. Proceedings of IISRO Multi Conference 2014, Bangkok, 140 - 146. ISBN No. 978-81-927104-33-13.

[17] Aithal, P. S., \& Shubhrajyotsna Aithal, (2016). Impact of On-line Education on Higher Education System. International Journal of Engineering Research and Modern Education (IJERME), 1(I), 225-235.

[18] Aithal, P. S. (2016). The concept of Ideal Strategy \& its realization using White Ocean Mixed Strategy, International Journal of Management Sciences and Business Research (IJMSBR), 5(4), 171179.

[19] Sridhar Acharya, P. and Aithal, P. S., (2016). Concepts of Ideal Electric Energy System for production, distribution and utilization. International Journal of Management, IT and Engineering (IJMIE), 6(1), 367-379.

[20] Aithal, P. S., (2016). Concept of Ideal Banking and Realization of it using Ubiquitous Banking. Proceedings of National Conference on Changing Perspectives of Management, IT, and Social Sciences in Contemporary Environment, Manegma 2016, SIMS, Mangalore, India, 14, 13-24. ISBN 978-93-52656523.

[21] Aithal, P. S., (2016). Smart Library Model for Future Generations. International Journal of Engineering Research and Modern Education (IJERME), 1(1), 693-703.

[22] Prasad, P.N. (1991). Strategy for optimization of molecular materials for nonlinear optics and photonics. Organic Molecules for Nonlinear Optics and Photonics, Springer Netherlands, 225-237.

[23] Larry, R. Dalton, Peter Günter, Mojca Jazbinsek, O-Pil Kwon, Philip A. S., (2015). Organic ElectroOptics and Photonics: Molecules, Polymers and Crystals, Cambridge University Press.

[24] Prasad, P.N. (1990). Nonlinear optical effects in organic materials. Nonlinear Optics in Solids, Springer Berlin Heidelberg, 304-327.

[25] Nagaraja, H. S., Upadhyaya, V., Rao, P.M., Aithal, P.S., Bhat, A.P., (1998). Organic nonlinear optical crystals of benzoyl glycine, Journal of crystal growth, 193(4), 674-678.

[26] Aithal, P.S. \& Rao, P.M., (1995). Novel nonlinear optical crystal of methyl-p-hydroxy benzoate. Journal of crystal growth, 153(1), 60-62.

[27] Sindhu Sukumaran, V. (2015). Third Order Optical Nonlinearity of Dye Doped Polymer. International Journal of ChemTech Research, 8(1), 300-303.

[28] Tomov, I. V., VanWonterghem, B., Dvornikov, A. S., Dutton, T. E., \& Rentzepis, P. M. (1991). Degenerate four-wave mixing in azo-dye-doped polymer films. JOSA B, 8(7), 1477-1482.

[29] Badran, H. A., (2015). Thermal properties of a new dye compound measured by thermal lens effect and Z-scan technique, Appl. Phys. B. 119, p.319.

[30] Aithal, P. S., Singh, R. P., Rao D. N. (2003). Optical limiting due to frequency up-converted fluorescence in DASPB-dye-doped polymer matrix. International Symposium on Optical Science and Technology, 229-239.

[31] Singh, R. P., Aithal, P. S., \& Rao, D. N. (2003). Optical limiting studies of Disperse Orange and Disperse Yellow in PMMA-MA matrix. International Symposium on Optical Science and Technology, 52-58.

[32] Shubrajyotsna Aithal, Aithal, P. S., and Bhat, G. K. (2011). Optical Nonlinearity of Dye-doped Polymer Film using Z-scan Technique, Second International Conference on Photonics 2011, 17-19 Kota Kinabalu, Malaysia, IEEEXplore. 62-66. ISBN 978-1-61284-265-3. 
[33] Shubrajyotsna Aithal, Aithal, P. S., and Bhat, G. K. (2011). Study of nonlinear absorption in a dye doped polymer film due to frequency up-converted fluorescence. Proceedings of the International Conference on Laser, Material Science and Communication, Dept. of Physics, University of Burdwan, West Bengal, Ed. U. Chatterjee and P.K. Chakrabarti, 107-109. ISBN : 978-93-80813-14-1.

[34] Shubhrajyotsna Aithal, Aithal, P. S., and Bhat, G. K. (2011). Nonlinear Absorption Studies of Disperse Orange Doped Polymer Film, Trends in Optics and Photonics II, Proceedings of International Conference on Trends in Optics and Photonics, December 7-9, 2011, Kolkata, India. Editors : Ajay Ghosh and Debesh Choudhury, 132-137. ISBN 978-81-908188-1-0.

[35] Fiorini, C., Charra, F., Nunzi, J. M., \& Raimond, P. (1997). Quasi-permanent all-optical encoding of noncentrosymmetry in azo-dye polymers. JOSA B, 14(8), 1984-2003.

[36] Denk, W., Strickler, J. H., \& Webb, W. W. (1990). Two-photon laser scanning fluorescence microscopy. Science, 248 (4951), 73-76.

[37] Shubrajyotsna Aithal, Sreeramana Aithal, and Gopalkrishna Bhat, (2012). Phase Conjugation in Two Photon Absorbing Dye films by Degenerate Four-wave Mixing, Proceedings of $3^{\text {rd }}$ International Conference on Photonics, 1-3 October 2012, Penang, Malaysia. IEEEXplore, 235-239 (2012). ISBN: 978-1-4673-1463-3. DOI 10.1109/ICP.2012.6379868.

[38] Shubrajyotsna Aithal, \& Aithal, P. S. (2012). Study of Phase Conjugated wave in DASPB dye-doped polymer films, Photonics Global Conference 2012, 13-16, December 2012, Nanyang Technical University, Singapore. Photonics Global Conference (PGC), Singapore, (pp. 1-5).

[39] Shubhrajyotsna Aithal, Aithal, P. S., and Bhat, G. K. (2015). Comparative Study on Azo dye-doped Polymer Films for Optical Phase Conjugation, International Journal of Science and Research (IJSR), $4(4), 436-441$.

[40] Shubrajyotsna Aithal, Aithal, P. S., \& Bhat, G. K. (2012). Study of Degenerate Four-Wave Mixing in Disperse Orange Dye-doped Polymer Film. Advanced Materials Research Journal, Trans Tech Publications (TTP), Switzerland, 584, 526-530.

[41] Shubrajyotsna Aithal, Aithal, P.S., \& Bhat, G. K. (2013). Degenerate four-wave mixing in DASPB dye-doped polymer film, published in Part IV Quantum Optics, Chapter 12, Advances in Laser Physics and Technology, Edited by Man Mohan, Anil Kumar Maini, Aranya A. Bhattacherjee and Anil K. Razdan under the imprint of Foundation Books, Cambridge University Press India Pvt Ltd. pp. 179 - 195, ISBN: 978-93-844634-1-0.

[42] Aithal, P.S., Prem Kiran, P., \& Rao, D. N. (2000). Self-trapping of optical beams in an unbiased photorefractive $\mathrm{Bi}_{12} \mathrm{SiO}_{20}$ :Fe crystal, Asian Journal of Physics, 9(2), 376 - 381.

[43] Shubhrajyotsna Aithal, Aithal, P. S., \& Bhat, G. K. (2013). Study of Optical Limiting and Optical Phase Conjugation in DASPB dye-doped polymer films. GSTF Journal of Physics and Applications (JPA), 1(1), 15-24.

[44] Aithal, S., Aithal P. S., Bhat, G. K. (2015). A Review on sustainable organic materials for optical limiting technology, International Journal of Management, IT and Engineering (IJMIE), 5(7), 527-544.

[45] Shubhrajyotsna Aithal, Aithal, P. S., \& Bhat, G. K. (2016). A Review on Organic Materials for Optical Phase Conjugation \& All-optical Switches. International Journal of Management, IT and Engineering (IJMIE), 6(1), 222-238.

[46] Aithal, P. S., Shailashree, V. T., Suresh Kumar, P. M. (2015). A New ABCD Technique to Analyze Business Models \& Concepts, International Journal of Management, IT and Engineering (IJMIE), 5(4), 409-423. 
[47] Aithal, P. S. (2016). Study on ABCD Analysis Technique for Business Models, Business strategies, Operating Concepts \& Business Systems, International Journal in Management and Social Science, 4(1), 98-115.

[48] Reshma, Aithal, P. S., Shailashree, V. T., \& Sridhar Acharya, P. (2015). An Empirical study on working from home - A popular E-business model, International Journal of Advance and Innovative Research, 2(2), 12-18.

[49] Aithal, P. S., Shailashree, V. T., \& Suresh Kumar, P. M. (2015). Application of ABCD Analysis Model for Black Ocean Strategy. International Journal of Applied Research (IJAR), 1(10), 331-337.

[50] Aithal, P. S., Shailashree, V. T., \& Suresh Kumar P. M., (2016). ABCD analysis of Stage Model in Higher Education. International Journal of Management, IT and Engineering (IJMIE), 6(1), 11-24.

[51] Aithal, P. S., Shailashree, V. T., \& Suresh Kumar, P. M. (2016). Analysis of NAAC Accreditation System using ABCD framework. International Journal of Management, IT and Engineering (IJMIE), 6(1), 30-44.

[52] Aithal, P. S., Shailashree, V. T., \& Suresh Kumar, P. M. (2016). Application of ABCD Analysis Framework on Private University System in India. International Journal of Management Sciences and Business Research (IJMSBR), 5(4), 159-170.

[53] Aithal, P. S., Shailashree, V. T., \& Suresh Kumar, P. M. (2016). The Study of New National Institutional Ranking System using ABCD Framework, International Journal of Current Research and Modern Education (IJCRME), 1(1), 389-402.

[54] Sridhar Acharya, P., Aithal, P. S. (2016). Concepts of Ideal Electric Energy System for production, distribution and utilization. International Journal of Management, IT and Engineering (IJMIE), 6(1), 367-379.

[55] Reshma, Aithal, P. S., Sridhar Acharya P. (2015). Relevance of On-line Office Administration through Working from Home in Future Education System. International Journal of Application or Innovation in Engineering \& Management, 4(4), 44 - 53.

[56] Padmanabha Shenoy, \& Aithal, P. S., (2016). A Study on History of Paper and possible Paper Free World. International Journal of Management, IT and Engineering (IJMIE), 6(1), 337-355.

[57] Aithal, P. S. (2015). Comparative Study on MBA Programmes in Private \& Public Universities - A case study of MBA programme plan of Srinivas University. International Journal of Management Sciences and Business Research (IJMSBR), 4(12), 106-122.

[58] Aithal, P. S., \& Shubhrajyotsna Aithal, (2016). Impact of On-line Education on Higher Education System. International Journal of Engineering Research and Modern Education (IJERME), I(1), 225-235.

[59] Aithal, P. S., \& Suresh Kumar, P. M. (2016). Analysis of Choice Based Credit System in Higher Education. International Journal of Engineering Research and Modern Education (IJERME), 1(1), 278284.

[60] Varun Shenoy, \& Aithal, P. S. (2016). Changing Approaches in Campus Placements - A new futuristic Model. International Journal of Scientific Research and Modern Education (IJSRME), 1(1), 766-776.

[61] Rogers, E. M., (1995). Diffusion of Innovation. The Free Press, NY.

[62] Aithal P. S. and Varambally K. V. M. (2006). Security Issues in Online Financial Transactions with Special Reference to Banking Industry. In Quality in Service Sector and Managerial Challenges - Allied Publisher Pvt. Ltd. 2006, ISBN: 81-7764-992-2, pp 103- 114. 
[63] Varambally, K. V. M., \& Aithal, P. S. (2009). Technological Management and Mobile Business Services in India - A Futuristic Approach, Proceedings on MIDISA - SAARC Conference on Change and Continuity : Management Prospects and Challenges, RIM, Thimphu, Bhutan, 121-139.

[64] Aithal, P. S., \& Varambally, K. V. M. (2009). Mobile Business Technology and Business Proliferation of Banks - A futuristic Approach. Amity Business Review - an Indian Journal, 10(1), 9-25.

[65] Aithal, P. S., and Shubhrajyotsna Aithal, (2015). Ideal Technology Concept \& its Realization Opportunity using Nanotechnology. International Journal of Application or Innovation in Engineering \& Management (IJAIEM), 4(2), 153-164.

[66] Aithal P. S., \& Shubhrajyotsna Aithal, (2015). Managing Anticipated Breakthrough Technologies of 21st Century - A Review. International Journal of Research \& Development in Technology and Management Sciences, 21(6), 112-133.

[67] Aithal P. S., (2015). Concept of Ideal Business \& Its Realization Using E-Business Model. International Journal of Science and Research (IJSR), 4(3), 1267-1274.

[68] Aithal P. S., \& Shubhrajyotsna Aithal, (2015). An Innovative Education Model to realize Ideal Education System. International Journal of Scientific Research and Management (IJSRM), 3(3), 2464 2469. 